JORGE HERNÁNDEZ

\title{
Las dinámicas del capitalismo
}

Si la nueva historia debe ser como creo, una reconstrucción del pasado captado en toda su amplitud y en toda su complejidad, tendrá que incorporar en sus cuadros y explicaciones la obra entera, tan rica, de las ciencias sociales, sus vecinas.

Fernand Braudel

D ARA muchos la historia no debe ser más que un recetario de fechas que nos ensalce los momentos gloriosos de nuestro pasado. Este ánimo arroja motivos para creer que nuestros héroes son intachables, incuestionables y monumentales. Sobra decir que este tipo de historiar excluye a los héroes anónimos y deja de lado a los hechos de cada día, tal vez no tan monumentales pero sí sustanciales para la vida de cada época.

Cuando Lucien Febvre y Marc Bloch se declaran por una "historia de los sentimientos" dejan una semilla que cultivaría magistralmente Fernand Braudel y que rompe con la historia tradicional, tan concentrada en lo bronceado. Es dentro de este ánimo que se ubica el libro de Manuel Cazadero, un libro en donde la cronología exacta y la heroicidad batallesca son reemplazadas por una interrelación amplia de cotidianidades que nos permite conocer mejor el pasado.

En una época en que nos encontramos con el ánimo especializador no sólo en las ciencias sociales, sino hasta en los talleres mecánicos o en los consultorios dentales, da gusto encontrarse con un historiador que procura entrelazar a los encantos de Clío con las otras ciencias sociales. Lejos de ser un estudio que se concentra en los altibajos económicos de épocas pasadas, el 
libro de Cazadero intenta relacionar esos vaivenes con las fluctuaciones sociales y políticas que provocaron.

Cazadero parte de la ley de correspondencia y presenta las relaciones y conjugaciones que existen entre cinco esferas principales de las épocas a historiar: Economía, Política, Sociedad, Ideología y Ecosis, entendida esta última como la relación bilateral entre el hombre y el medio natural que lo rodea. Se trata de cinco esferas que se entretejen, afectándose mutuamente, y cuyo análisis permite realizar un quehacer histórico que va más allá de reseñar una simp̧le cronología estadístico-cronológica.

La escuela de Les Anales, y felizmente muchos historiadores actuales, comprendı́ que la historia debía interesarse por los chismes y las cartas amorosas con igual interés que el que se le brinda a los edictos y libros de contabilidad. La pintura, la poesía y la música, al fusionarse con los climas, el comercio y las comunicaciones nos brindan la posibilidad de observar un cuadro descriptivo mucho más ilustrativo que una gráfica, por más matemáticamente exacta que ésta sea y por más colores que decoren sus líneas.

De esta manera, encontramos en Desarrollo, crisis e ideolosía en la formación del capitalismo un estudio que pinta a la Europa medieval de una manera dinámica por el juego dialéctico de las cinco esferas que propone Cazadero. Una Europa del siglo $\mathrm{X}$ en donde la Ecosis refiere al continente como "un inmenso mar de árboles", Roma con veinticinco mil habitantes, el Mediterráneo como una inmensa alberca musulmana, magiares jineteando por doquier y al norte los vikingos navegantes. Económicamente, Cazadero nos habla de un "comercio ocasio" nal", parafraseando a Henri Pirenne. Socialmente, nos encontramos con siervos invendibles, adscritos a la tierra, y, por otro lado, una nobleza que engloba a Caballeros, Hidalgos, Condes, Duques y Reyes. Políticamente, ha desaparecido el estado centralista e Ideológicamente, la sociedad vive en un mundo mágico sobrenatural. Un mundo en donde está siempre la mano amenazante, y a la vez, reconfortante, de Dios y en donde los humanos conviven con una lista interminable de seres ultraterrenos. Al realizar este tipo de análisis se puede ir siguiendo el curso de la historia, conociendo las transformaciones que se van dando en cada una de las esferas, interrelacionándolas.

Con la introducción del arado de hierro el hombre logra abrir surcos más profundos, mejor protección para la semilla, y consigue trabajar las tierras duras del norte de Europa, tierras 
que los arados antiguos de los romanos no lograron surcar. Este giro ecosístico da pie a la aparición de un excedente económico, la riqueza, y al valor de uso de las cosas se le agrega un valor de cambio. Socialmente surge una clase comerciante que conocemos como burgueses porque su aparición se vincula con el resurgimiento de las ciudades. Al necesitar mayor protección, los siervos le confieren mayor poder político a los reyes y señores feudales e ideológicamente lo racional y racionalista empieza a sustituir a lo mágico-misterioso.

Como se puede observar, Cazadero más que ir enumerando fechas, va trazando flechas que entrelazan a todas las esferas del pasado y que describen mejor esa realidad. El conglomerado de flechas que vuelan sobre Europa a partir del siglo XIV permiten conocer la formación del capitalismo, proceso que hasta nuestros días continúa en boca y en vida de todos. Se trata de una época intrincada, cuyo complicado enredo de flechas refiere una cadena cronológica interesante y dificil de tomar a la ligera. Socialmente es una época de grandes guerras, recordemos la llamada posteriormente como "la de los cien años", además de ser el "Siglo de las Pestes", imaginemos la Peste Negra de 1348. Esta situación provoca cambios en el comercio que, además, se ve afectado por las hambres devastadoras provocadas, de 1315 a 1317, por lluvias ininterrumpidas que arruinan las cosechas. Este desastre económico tiene su flecha con la ecosis que vive la "pequeña glaciación" provocando cambios significativos en la temperatura europea, lo cual contribuyó a la terrible escasez de alimentos. De esta sucesión de flechas se desprende la que se refiere directamente al objeto de estudio de Cazadero: la formación del capitalismo, en donde su desarrollo, su crisis y su ideología se entienden también a través de las flechas que aparecen en esta forma de historiar.

De aquí que Cazadero se aboque a perseguir la dirección de las flechas del capital, palabra que denomina a la "riqueza que se reproduce a sí misma, en forma ampliada y por medios económicos". Durante los siglos XI al XIII aparece una dualidad de capital: el mercantil y el usuario o de préstamo. Es en el siglo XIV cuando el capital incursiona en la producción arrojando, de acuerdo a la ley de correspondencia, nuevas flechas que alteran a otras esferas: cambios en las relaciones sociales, cambios ideológicos y virajes políticos.

Cazadero pretende que su análisis sea una visión global en donde las cinco esferas ya mencionadas ocupan un mismo 
nivel de importancia. Sin embargo, parece que la esfera de lo económico, la historia de la fenomenología económica, tiene una preponderancia sobre la ecosis, lo social, lo político y lo ideológico. De cualquier forma, se trata de un estudio que analiza y desentraña los avatares y accidentes de la génesis y desarrollo del capitalismo, permitiéndonos conocerlo mejor.

Es, además, un trabajo que sigue los pasos de esa forma de historiar, más amena y más humana, que cultivó Braudel.

La nouvelle histoire de la escuela de los Anales ha demostrado que el pasado también puede ser estudiado por medio de la investigación de hábitos y recetas culinarias, cuadros renacentistas y costumbres cotidianas. Manuel Cazadero nos presenta así un trabajo que confirma que el quehacer histórico no tiene porqué ser insípido ni mucho menos rigurosamente especialista. 